\title{
Analiza możliwości stosowania systemów faliście giętkich przewodów ze stali nierdzewnej w instalacjach gazowych w budynkach w Polsce
}

\author{
Analysis of the possibilities of using stainless steel flexible hose systems in gas \\ installations in Poland
}

\author{
Tomasz Minor \\ Instytut Nafty i Gazu - Państwowy Instytut Badawczy
}

\begin{abstract}
STRESZCZENIE: Obecnie w Polsce najważniejszym aktem prawnym określającym wymagania dotyczące budowy instalacji gazowych w budynkach i materiały, jakie można w tych instalacjach stosować, jest Rozporządzenie Ministra Infrastruktury z dnia 12 kwietnia 2002 r. w sprawie warunków technicznych, jakim powinny odpowiadać budynki i ich usytuowanie (Dz.U. z 2015 r. poz. 1422 z późn. zm.). Dopuszcza ono do stosowania rury stalowe przewodowe bez szwu bądź rury stalowe przewodowe ze szwem, łączone przez spawanie oraz z użyciem połączeń gwintowanych, lub rury miedziane łączone poprzez lutowanie lutem twardym. Z uwagi na fakt, że Polska Norma PN-EN 1775:2009 dopuszcza stosowanie systemów faliście giętkich przewodów ze stali nierdzewnej, jak również inne materiały, m.in. tworzywa sztuczne czy też systemy ze stali nierdzewnych łączonych poprzez zaprasowywanie, oraz ze względu na pojawiające się zapytania producentów systemów faliście giętkich przewodów ze stali nierdzewnej dotyczące możliwości ich używania w Polsce przeprowadzono analizę możliwości stosowania systemów faliście giętkich przewodów ze stali nierdzewnej do budowy instalacji gazowych w Polsce. W artykule przybliżone zostały przepisy obowiązujące w Polsce oraz w wybranych krajach UE regulujące możliwość wykorzystania faliście giętkich przewodów ze stali nierdzewnej w instalacjach gazowych budynków. Badaniom zostały poddane z punktu widzenia autora najważniejszych cech systemów faliście giętkich przewodów ze stali nierdzewnej, mając na uwadze te właściwości, które mogą mieć największy wpływ na bezpieczeństwo ich użytkowania. Badania przeprowadzono na wytypowanych trzech różnych systemach dostępnych na rynku UE. Badanymi właściwościami były: szczelność, zdolność zginania, wytrzymałość na ciśnienie wewnętrzne, odporność na uderzenie, wytrzymałość na wgniecenie, wytrzymałość na rozciąganie, szczelność w przypadku ognia. Badania zostały wykonane na podstawie metodyki opisanej w Polskiej Normie PN-EN 15266:2009. We wszystkich badaniach uzyskano pozytywne wyniki. Na koniec dokonano oceny możliwości stosowania systemów faliście giętkich przewodów ze stali nierdzewnej do budowy instalacji gazowych w budynkach oraz zaproponowano dodatkowe wymagania, jakie powinny spełniać omawiane systemy.
\end{abstract}

Słowa kluczowe: przewody faliste, instalacje gazowe, przewody faliście giętkie ze stali nierdzewnej.

ABSTRACT: Currently in Poland, the most important legal act specifying the requirements and materials that can be used for the construction of gas installations in buildings is the Regulation of the Minister of Infrastructure on the technical conditions to be met by buildings and their location (Journal of Laws 2015 item 1422 as amended). It permits the use of seamless steel or welded steel carrier pipes, and threaded connections or copper pipes joined by brazing. Due to the fact that the Polish Standard PN-EN 1775:2009 (PN-EN 1775:2009) allows the use of corrugated stainless steel hoses as well as other materials, including plastics or stainless steel systems joined by crimping, as well as emerging inquiries of manufacturers of corrugated stainless steel hoses concerning the possibility of their use in Poland, an analysis of the possibility of using corrugated stainless steel hoses for gas installations in Poland was conducted. The article presents the provisions in force in Poland and in selected EU countries regulating the possibility of using corrugated stainless steel hoses in gas installations in buildings. Research was carried out to examine the most important, form the author's point of view, characteristics of corrugated stainless steel hose systems, taking into account those properties that may have the greatest impact on their safety. The research was carried out on three selected systems available on the EU market. The properties tested were tightness, bending capacity, internal pressure strength, impact resistance, dent resistance, tensile strength, fire tightness. The tests were carried out based on the methodology described in the Polish Standard PN-EN 15266:2009. All tests gave positive results. Finally, the feasibility of using corrugated stainless steel hose systems in gas installations in buildings was assessed, and additional requirements to be met by these systems were proposed.

Key words: flexible pipes, gas installations, flexible stainless steel pipes.

Autor do korespondencji: T. Minor, e-mail: tomasz.minor@inig.pl

Artykuł nadesłano do Redakcji: 08.11.2019 r. Zatwierdzono do druku: 05.03.2020 r. 


\section{Przepisy techniczne i prawne, jakim powinny odpowiadać faliście giętkie przewody ze stali nierdzewnej}

Zgodnie z ustawą o wyrobach budowlanych (Ustawa o wyrobach budowlanych, 2016) wyroby budowlane wprowadzane do obrotu powinny być oznakowane znakiem budowlanym w przypadku, gdy „Wyrób budowlany nie jest objęty normą zharmonizowaną, dla której zakończył się okres koegzystencji, o którym mowa w art. 17 ust. 5 rozporządzenia $\mathrm{Nr}$ 305/2011, i dla którego nie została wydana europejska ocena techniczna", i powinny mieć wystawioną krajową deklarację właściwości użytkowych.

Deklarowanie właściwości użytkowych wyrobów powinno odbywać się na podstawie Polskiej Normy wyrobu lub krajowej oceny technicznej.

$\mathrm{Z}$ uwagi na fakt, że norma, która obejmuje swoim zakresem faliście giętkie przewody ze stali nierdzewnej, czyli PN-EN 15266:2009, nie została zharmonizowana, obecnie nie można znakować wyrobów znakiem CE na podstawie zgodności z tą normą. Elementy instalacji gazowej, jakimi są faliście giętkie systemy ze stali nierdzewnej, ze względu na zastosowanie $\mathrm{w}$ instalacjach $\mathrm{w}$ miejscach podlegających wymaganiom dotyczącym bezpieczeństwa pożarowego zgodnie z rozporządzeniem Ministra Infrastruktury i Budownictwa w sprawie sposobu deklarowania właściwości użytkowych wyrobów budowlanych oraz sposobu znakowania ich znakiem budowlanym (Rozporządzenie z 17 listopada 2016, załącznik 1, poz. 28) podlegają ocenie w 1 systemie oceny i weryfikacji stałości właściwości użytkowych w systemie krajowym i powinny posiadać certyfikat wydany przez jednostkę certyfikującą.

Dokumentem określającym wymagania dla elementów instalacji gazowych w budynkach jest norma PN-EN 1775:2009. Norma ta w swoim zakresie dopuszcza do stosowania systemy faliście giętkich przewodów ze stali nierdzewnej, jak i inne, m.in. systemy z tworzyw sztucznych czy też systemy z rur ze stali nierdzewnych. W artykule Wróblewskiej (2010) dokonano analizy stanu wiedzy i praktyki w zakresie wykorzystywania rur wielowarstwowych $\mathrm{w}$ instalacjach gazowych, stosowanych już za granicą, a niedopuszczonych do stosowania w Polsce. Omówiono w nim wady i zalety stosowania tych rur w instalacjach gazowych pod względem oddziaływania na środowisko, bezpieczeństwa użytkowania oraz z punktu widzenia efektywności ekonomicznej. Wspomniano o systemach faliście giętkich przewodów ze stali nierdzewnej stosowanych w innych krajach jako możliwej alternatywie dla budowy instalacji gazowych w budynkach. W artykułach autora niniejszej publikacji (Minor, 2017a, 2017b) przedstawiono informacje na temat możliwości poprawy bezpieczeństwa użytkowania instalacji gazowych, jak również analizę stanu techniczno-prawnego instalacji gazowych w Polsce pod względem bezpieczeństwa ich eksploatacji.

Na rynku można znaleźć również informacje mówiące o ryzyku związanym z tymi produktami, mianowicie o uszkodzeniach podczas wyładowań atmosferycznych.

Przewody faliste nie są tak wytrzymałe jak rury stalowe i w wyniku wyładowania atmosferycznego mogą ulec uszkodzeniu.

W artykule Brady'ego (2015) opisano problemy związane z budową instalacji gazowych z systemów faliście giętkich, zwanych w USA „CSST”. Od momentu wprowadzenia w Stanach Zjednoczonych w 1988 r. system ten stał się coraz popularniejszym sposobem dostarczania gazu ziemnego. Producenci szacują, że ponad 50\% wszystkich instalacji gazowych w nowych domach, czyli około 500000 domów rocznie, wykorzystuje systemy CSST.

Według producentów głównymi problemami związanymi ze stosowaniem systemów CSST jest nienależyte, niefachowe wykonywanie instalacji gazowych, brak odpowiednich uziemień tych systemów oraz budynków, w których takie systemy są montowane.

W innym artykule (Friedman, 2015) można znaleźć bardziej sceptyczne informacje dotyczące bezpieczeństwa stosowania systemów CSST w USA. Opisano przypadki, w których pomimo istnienia instalacji uziemiających wyładowania atmosferyczne mogły spowodować pożary w domach $\mathrm{z}$ instalacjami CSST. Eksperci uważają, że awarie systemów CSST spowodowane są innymi wadami w budownictwie. Szacuje się jednak, że obecnie nawet około 30-60\% pożarów domów spowodowanych jest awarią instalacji gazowych wykonanych z systemów CSST powstałą w wyniku wyładowań atmosferycznych.

\section{Przepisy i specyfikacje techniczne stosowane w Polsce}

Najważniejszym dokumentem zawierającym wymagania dotyczące budowy, projektowania, konserwacji i eksploatacji instalacji gazowych w budynkach jest Rozporządzenia Ministra Infrastruktury z dnia 12 kwietnia 2002 r. w sprawie warunków technicznych, jakim powinny odpowiadać budynki i ich usytuowanie (Dz.U. z 2015 r. poz. 1422). Wymagania te opisane są w rozdziale 7 tego rozporządzenia - Instalacja gazowa na paliwa gazowe.

W rozporządzeniu (Rozporządzenie Ministra Infrastruktury w sprawie warunków technicznych, jakim powinny odpowiadać budynki i ich usytuowanie, 2015 ) określono m.in. rodzaje materiałów, z jakich można wykonywać instalacje gazowe w budynkach. Zapisy określające te materiały znajdują się w $§ 163$ : 
ust. 1a. Przewody instalacji gazowej powinny być wykonane w sposób zapewniający spełnienie wymagań szczelności i trwałości określonych w Polskiej Normie dotyczącej przewodów gazowych dla budynków.

ust. 2. Przewody instalacji gazowej, począwszy od 0,5 m przed zewnętrzną ścianą budynku do kurków odcinających przed gazomierzami w budynkach mieszkalnych wielorodzinnych lub do odgałęzień lokali użytkowych w budynkach użyteczności publicznej, powinny być wykonane z rur stalowych bez szwu bądź z rur stalowych ze szwem przewodowych, zgodnych z wymaganiami przedmiotowych Polskich Norm, łączonych przez spawanie.

ust. 3. Przewody instalacji gazowej w budynkach mieszkalnych jednorodzinnych, zagrodowych i rekreacji indywidualnej, począwszy od 0,5 m przed zewnętrzną ścianą budynku do wyprowadzenia poza lico wewnętrzne tej ściany, powinny być wykonane z rur, o których mowa w ust. 2.

ust. 4. W budynkach mieszkalnych jednorodzinnych, budynkach w zabudowie zagrodowej i budynkach rekreacji indywidualnej przewody instalacji gazowej, a w pozostałych budynkach tylko przewody za gazomierzami lub odgałęzieniami prowadzącymi do odrębnych mieszkań lub lokali użytkowych, powinny być wykonane $z$ rur, o których mowa w ust. 2, lączonych również z zastosowaniem połączeń gwintowanych lub z rur miedzianych lączonych przez lutowanie lutem twardym. Dopuszcza się stosowanie innych sposobów lączenia rur, jeżeli spełniają one wymagania szczelności i trwałości określone w Polskiej Normie dotyczącej przewodów gazowych dla budynków.

ust. 5. Po zewnętrznej stronie ścian budynku nie mogą być prowadzone przewody gazowe wykonane:

1) z rur stalowych, jeżeli służą do rozprowadzania paliw gazowych zawierających parę wodną lub inne składniki ulegające kondensacji w warunkach eksploatacyjnych;

2) z rur miedzianych.

Jak wynika z powyższych zapisów, rozporządzenie to nie pozwala na zastosowanie faliście giętkich przewodów ze stali nierdzewnej do budowy instalacji gazowych w budynkach.

Norma PN-EN 1775:2009 Dostawa gazu - Przewody gazowe dla budynków - Maksymalne ciśnienie robocze równe 5 bar lub mniejsze - Zalecenia funkcjonalne określa ogólne wymagania dotyczące projektowania, budowy, badań, przekazania do eksploatacji oraz obsługi i konserwacji przyłączy i instalacji gazowej w budynkach. Jako instalację określa m.in. przewody gazowe montowane od punktu dostawy gazu, kończące się na połączeniach wlotowych odbiorników gazowych.

W punkcie 5.2 tej normy opisane są metody łączenia przewodów. Według normy do takich połączeń można stosować:
- połączenia gwintowane (zgodne z PN-EN 10226-1 i PNEN 10226-2) do DN50;

- połączenia spawane, lutowanie twarde i miękkie oraz zgrzewanie;

- połączenia mechaniczne.

Wydanie normy (PN-EN 1775:2009) z roku 2009 zostało rozszerzone w stosunku do wydania z 2001 roku o dwie metody wykonywania połączeń:

- połączenia zaciskowe,

- połączenia zaciskowe rur miedzianych,

- połączenia zaciskowe rur wielowarstwowych i PEX;

- systemy łączenia falistych przewodów rurowych ze stali nierdzewnej.

Systemy falistych przewodów rurowych ze stali nierdzewnej omówione są w załączniku E wspomnianej normy (PN-EN 1775:2009).

W punkcie E.2 załącznika Składniki systemu zapisano: „Zaleca się, aby tylko rury i odpowiadające im kształtki, określone przez producenta, były stosowane do budowy systemu dotyczącego falistych przewodów giętkich ze stali nierdzewnej".

„Dla każdego systemu zaleca się, aby byly stosowane rury i ksztaltki zgodne z EN 15266 (systemy falistych przewodów gazowych giętkich ze stali odpornej na korozję)".

Zapisy punktu E.3 normy (PN-EN 1775:2009) pt. Procedura łączenia systemów falistych przewodów rurowych giętkich ze stali nierdzewnej zalecają, aby procedura łączenia systemów była określona przez wytwórcę i zawierała co najmniej:

- „potwierdzenie, że zgodnie z zaleceniami wytwórcy, różne składniki systemu pasują do siebie (rura, uszczelka, kształtki...);

- listę i opis specjalistycznych narzędzi koniecznych do wykonywania połączeń, wraz z instrukcjami stosowania i zalecanym planem przeglądów i utrzymania".

Dodatkowo zapisano: „Jeżeli ponowne zamontowanie kształtki uprzednio zdemontowanej wymusza wymianę co najmniej jednego składnika kształtki (np. uszczelka), zaleca się, aby to było dopuszczalne tylko wtedy, gdy jest przewidziane i opisane w instrukcji dostarczonej przez wytwórcę".

Wspomniana norma (PN-EN 15266:2009) określa m.in. wymagania dotyczące projektowania, w tym stosowanych materiałów, wytwarzania, badań, cechowania oraz dokumentowania giętkich falistych przewodów rurowych (PLT) ze stali odpornych na korozję, wykorzystywanych w budynkach (PN-EN 15266:2009). Należy nadmienić, że norma ta nie ma zastosowania do elastycznych przewodów służących do podłączania urządzeń spalających paliwa gazowe.

W pkt 4 normy (PN-EN 15266:2009) pt. Wymagania projektowe zapisy określają wymagania dotyczące:

- materiałów;

- wymiarów nominalnych i spadków ciśnienia - wymiary 
nominalne należy dobrać z wymiarów podanych w normie EN ISO 10380:2003;

- gwintów - zgodnych z EN 10226-1;

- złączy PLT (wymagania dla pojedynczego złącza do przyłączania metodą mechaniczną, w którym szczelność jest osiągana z uszczelnieniem lub bez);

- uszczelek i środków uszczelniających;

- środowiska - odporności m.in. na korozję, temperaturę;

- wsporników;

- przewodności elektrycznej;

- powłok.

W 5 punkcie normy (PN-EN 15266:2009) pt. Wymagania eksploatacyjne $i$ badawcze przedstawione są poszczególne wymagania eksploatacyjne, jakie muszą spełnić systemy faliście giętkich przewodów ze stali nierdzewnej, a także badania oraz metody badawcze, jakie należy wykonać na próbkach przygotowanych do badań.

Załącznik ZA normy opisuje m.in. warunki oznakowania CE systemu faliście giętkiego przewodu rurowego do gazu ze stali nierdzewnej. Jednak - jak już wcześniej wspomniano - oznakowanie CE nie ma zastosowania w przypadku wyrobów objętych normą (PN-EN 15266:2009) ponieważ nie została ona zharmonizowana z rozporządzeniem (UE) 305/2011, dotyczącym wyrobów budowlanych. W tablicy ZA1 przedstawiono wymagania i właściwości wg mandatu M/131 Rury, zbiorniki i osprzęt niestykajacy się z woda przeznaczona do spożycia przez ludzi, udzielonego zgodnie z dyrektywą UE Wyroby budowlane (89/106/EWG).

W załączniku ZA normy (PN-EN 15266:2009) znajduje się także ostrzeżenie: „W odniesieniu do systemu faliście giętkiego przewodu rurowego do gazu ze stali odpornej na korozję objętego zakresem niniejszej Normy Europejskiej mogą być zastosowane inne wymagania $\mathrm{i}$ inne dyrektywy UE niemające wpływu na ich przydatność użytkową zgodnie z przeznaczeniem”.

\section{Przepisy stosowane w innych krajach UE}

W wybranych krajach UE przepisy dotyczące możliwości wykorzystania systemów faliście giętkich przewodów ze stali nierdzewnej nie są jednolite i oprócz Europejskiej Normy EN 15266 wybrane kraje stosują dodatkowe przepisy regulujące wymagania dotyczące użycia tych systemów, a nawet określają dodatkowe wymagania czy też warunki badań, różne od zapisów normy EN 15266.

W Wielkiej Brytanii systemy faliście giętkich przewodów ze stali nierdzewnej są dopuszczone do stosowania jako materiały do budowy instalacji gazowych w budynkach. Wymagania w stosunku do instalacji wykonywanych z tych systemów określone są w odrębnych przepisach, m.in. w rozporządzeniu L56
Bezpieczeństwo w instalacji i użytkowaniu systemów i urządzeń gazowych. Pozostałymi podstawowymi dokumentami związanymi ze stosowaniem faliście giętkich przewodów ze stali nierdzewnej w instalacjach gazowych budynków są m.in. norma BS 6891:2015, która w rozdziale 6 Materials and components (Materiały i komponenty) w podpunkcie 6.2 p. 3 określa wymagania dla systemów faliście giętkich przewodów ze stali nierdzewnej. Rury faliste (ze stali nierdzewnej) powinny być zgodne z BS 7838:1996 lub BS EN 15266:2007. Jak widać, systemy te mogą spełniać wymagania normy BS 7838, które różnią się od wymagań normy BS EN 15266. Tabela 1 przedstawia różnice $\mathrm{w}$ wymaganiach pomiędzy tymi normami (BS 7838, BS EN 15266).

Tabela 1. Podstawowe różnice w badanych cechach

Table 1. Basic differences in the characteristics tested

\begin{tabular}{|l|c|c|}
\hline \multicolumn{1}{|c|}{ Badana cecha } & BS 7838:1996 & $\begin{array}{c}\text { BS EN } \\
\text { 15266:2007 }\end{array}$ \\
\hline \hline Test połączenia spawanego & $\mathrm{x}$ & - \\
\hline Odporność na ozon & $\mathrm{x}$ & - \\
\hline Odporność na skręcanie & $\mathrm{x}$ & - \\
\hline $\begin{array}{l}\text { Próba momentów montażowych } \\
\text { dla złączek końcowych }\end{array}$ & $\mathrm{x}$ & - \\
\hline $\begin{array}{l}\text { Badanie momentu dokręcania dla } \\
\text { połączeń gwintowych }\end{array}$ & $\mathrm{x}$ & - \\
\hline $\begin{array}{l}\text { Próba skręcania na wewnętrznie } \\
\text { gwintowanym połączeniu }\end{array}$ & $\mathrm{x}$ & - \\
\hline $\begin{array}{l}\text { Próba zginania na wewnętrznie } \\
\text { gwintowanym połączeniu }\end{array}$ & - & $\mathrm{x}$ \\
\hline $\begin{array}{l}\text { Trwałość uszczelnień elastome- } \\
\text { rowych }\end{array}$ & - & $\mathrm{x}$ \\
\hline Penetracja cieczy pod osłonę & - & $\mathrm{x}$ \\
\hline Kontrola wymiarów & - & $\mathrm{x}$ \\
\hline Odporność na zgniatanie & - & - \\
\hline Odporność na uderzenie & - & - \\
\hline Reakcja na ogień & & $\mathrm{x}$ \\
\hline Maksymalne obciążenie przy do- & & - \\
\hline
\end{tabular}

We Francji przepisami określającymi wymagania dla instalacji gazowych są m.in. NF DTU 61.1 P1 2006 Prace budowlane - Instalacje gazowe w pomieszczeniach mieszkalnych, Czesść 1: terminologia oraz NF DTU 61.1 P2 2006 Prace budowlane - Instalacje gazowe w pomieszczeniach mieszkalnych, Czesść 2: Klauzule techniczne-Przepisy ogólne. Dokumenty te, z uwagi na rok ich powstania, nie odnoszą się do faliście giętkich systemów ze stali nierdzewnej, dlatego przepisem określającym warunki stosowania tych systemów była m.in. norma XP E29-826, wydana w 2017 r. przez AFNOR (Francuskie 
Stowarzyszenie Normalizacyjne), dotycząca systemów z rur falistych ze stali nierdzewnej do gazu o ciśnieniu roboczym do 2 barów. Dokument ten określa wymagania dotyczące materiałów, projektowania, produkcji, badań, oznakowania, dokumentacji, a także dystrybucji gazów w instalacjach gazowych dla sektorów: prywatnego, mieszkalnego, komercyjnego i przemysłowego o maksymalnym ciśnieniu roboczym (MOP) mniejszym lub równym 0,5 bar w zakresie średnic nominalnych między DN 10 i DN 50 (klasa 1) oraz w instalacjach gazowych jak wyżej o maksymalnym ciśnieniu roboczym mniejszym lub równym 2 bar w zakresie średnic nominalnych między DN 10 a DN 25 (klasa 2). Standard ten ma charakter eksperymentalny i nie jest obligatoryjny do stosowania, jednak przywoływany w umowie jest wiążący dla stron (XP E29-826, 2017). W przypadku wymagań dotyczących materiałów standard ten jest zbieżny ze standardem CCH 2007-01 oraz NF EN 15266:2007. Z uwagi na fakt, że obowiązujące dotychczas rozporządzenie dotyczące wykonywania instalacji gazowych w budynkach pochodziło z roku 1977 i nie nadążało za pojawiającymi się rozwiązaniami na rynku, w 2018 roku wydano nowe - Rozporządzenie z dnia 23 lutego 2018 r. w sprawie zasad technicznych i bezpieczeństwa, mających zastosowanie do instalacji gazów palnych w budynkach mieszkalnych jedno- lub wielorodzinnych, w tym w pomieszczeniach wspólnych. Rozporządzenie to dopuszcza do stosowania elastyczne przewody faliste ze stali nierdzewnej, określając również niektóre wymagane cechy, m.in.:

- w przypadku pożaru konstrukcja powinna zapewnić nierozprzestrzenianie się ognia oraz niespowodowanie wybuchu;

- odporność na zgniatanie ma być taka, aby właściwości eksploatacyjne, w tym właściwości uszczelniające, nie były osłabione;

- odporność na drgania;

- odporność na ciśnienie wewnętrzne zgodne z minimalnym i maksymalnym ciśnieniem roboczym instalacji, w której są zainstalowane;

- elementy falistych węży metalowych mają pozostać wodoszczelne w normalnych przypadkach użytkowania;

- przewody faliste mają wytrzymać naprężenia skręcające/ zginające, którym podlegają podczas użytkowania, i powinny pozostać wodoszczelne;

- ciągłość elektryczną;

- powinny być tak zaprojektowane, aby nie wymagały wykonywania dalszych konserwacji;

- powinny być odporne na warunki środowiskowe, w jakich są zainstalowane.

Tabela 2 przedstawia różnice w wymaganych właściwościach określonych w dwóch normach: CCH 2007-01:2014 i NF EN 15266:2007.
Tabela 2. Podstawowe różnice w badanych cechach

Table 2. Basic differences in the characteristics tested

\begin{tabular}{|l|c|c|}
\hline \multicolumn{1}{|c|}{ Badana cecha } & $\begin{array}{c}\text { CCH 2007- } \\
\text { 01:2014 }\end{array}$ & $\begin{array}{c}\text { NF EN } \\
\mathbf{1 5 2 6 6 : 2 0 0 7}\end{array}$ \\
\hline \hline Odporność na niską temperaturę & - & $\mathrm{x}$ \\
\hline $\begin{array}{l}\text { Maksymalne obciążenie przy } \\
\text { dopuszczalnym odkształceniu }\end{array}$ & - & $\mathrm{x}$ \\
\hline
\end{tabular}

Na Słowacji systemy faliście giętkich przewodów ze stali nierdzewnej są dopuszczone do stosowania - wymagania dotyczące tych systemów przedstawia reguła techniczna TPP 704012009 Domove plynovody - Odberné plynové zariadenia na zemný plyn v budovách (Gazociagi krajowe-elementy do dystrybucji gazu w budynkach), wydana przez Słowackie Stowarzyszenie Gazu i Oleju (SPNZ). Dokument ten (TPP 704 01, 2009) jest zgodny z normą STN EN 45020:2007 (Normalizacja i dziedziny związane - Terminologia ogólna). Ta reguła techniczna (TPP 704 01, 2009) jest również zgodna z normą europejską EN 1775:2008 i zawiera bardziej szczegółowe wymagania dotyczące dystrybucji gazu w budynkach o ciśnieniu roboczym do $10 \mathrm{kPa}$.

W pkt. 5 omawianej reguły technicznej (TPP 704 01, 2009), a konkretnie w podpunkcie 5.2 Orurowanie, zezwala się na wykonywanie instalacji z systemów rur faliście giętkich ze stali nierdzewnej.

W zakresie materiałów stosowanych do budowy instalacji gazowych, napraw i rozbudowy dopuszcza się m.in.:

- $\quad$ stal (np. zgodnie z normą STN EN 10208-1);

- miedź (według STN EN 1057);

- tworzywo sztuczne (np. PE 100 lub wielowarstwowy materiał PEX-AL-PEX lub PE-AL-PE) do użytku z zewnętrznym gazociągiem umieszczonym w ziemi;

\section{- faliście elastyczne przewody wykonane ze stali nie-} rdzewnej PLT (np. zgodnie z EN 15266).

Druga reguła techniczna - TPP 70404 reguluje warunki dla projektowania, instalowania, konserwacji i badania systemów faliście giętkich przewodów ze stali nierdzewnej do budowy instalacji gazowych w budynkach (PLT) przy maksymalnym ciśnieniu roboczym do $50 \mathrm{kPa}$ włącznie (0,5 bar) i zakresie wymiarów nominalnych od DN 10 do DN 50 włącznie.

W rozdziale 3 Przepisy ogólne tej reguły technicznej (TPP 704 04, 2016) zapisano:

p. 3.1. Do instalowania, rozbudowy, przebudowy i naprawy domowych instalacji gazowych z użyciem przewodów falistych (PLT) można używać tylko tych wyrobów, które są odpowiednie do tego celu. Produkty muszą spełniać wymogi określone w normie STN EN 15266 i posiadać deklarację właściwości użytkowych. Deklaracja powinna zostać wystawiona zgodnie z odpowiednimi przepisami.

p. 3.2. Podczas montażu systemy (PLT) mogą być łączone 
z wykorzystaniem połączeń mechanicznych gwintowanych zgodnych z normą EN 1775 i TPP 70401.

W Niemczech przewody faliście giętkie ze stali nierdzewnej dopuszczono do stosowania w budowie instalacji gazowych w budynkach. Wymagania dotyczące budowy instalacji gazowych zapisane zostały w wytycznych technicznych dla instalacji gazowych DVGW G 600 Technische Regel für Gasinstallationen. Wytyczne techniczne (DVGW G 600, 2017) dla instalacji gazowych (DVGW-TRGI) dotyczą projektowania, budowy, modyfikacji, konserwacji i eksploatacji instalacji gazowych, zgodnie z wytycznymi technicznymi DVGW G 260 - z wyjątkiem gazu płynnego w budynkach i na lądzie o ciśnieniu roboczym do $0,1 \mathrm{MPa}$.

Wytyczne techniczne nie wprowadzają zmian w innych regulacjach prawnych, dotyczących m.in. przepisów budowlanych, państwowych przepisów przeciwpożarowych oraz w stosownych przypadkach przepisów związanych z bezpieczeństwem produktów.

W punkcie 5.2.3.2 wytycznych technicznych opisano wymagania dla rur falistych ze stali nierdzewnej do ciśnień roboczych do $100 \mathrm{hPa}$. Według wytycznych technicznych (DVGW G 600, 2017) zestawy elastycznych rur falistych ze stali nierdzewnej w budynkach na gaz o ciśnieniu roboczym do 0,05 MPa powinny być zgodne z wymiarami i specyfikacją wytycznych technicznych DVGW 5616. Wytyczne techniczne DVGW 5616 zastąpiły wcześniejsze wytyczne DVGW VP616. W obecnych wytycznych technicznych w stosunku do poprzednich usunięto wszystkie wymagania konstrukcyjne, które są opisane w normie DIN EN 15266. Pozostawiono m.in. wymagania, które zapewniają bezpieczne działanie w Niemczech, w tym specjalne wymagania dotyczące uszczelek, w przypadku kiedy są one wymagane, oraz wymagania, które muszą być spełnione w celu zapewnienia odporności termicznej.

Te wytyczne dotyczą systemów faliście giętkich rur ze stali nierdzewnej zgodnych z DIN EN 15266, do maksymalnego ciśnienia roboczego (MOP) 100 mbar w instalacjach gazowych domowych i 500 mbar w instalacjach komercyjnych. Zakres średnic nominalnych wynosi od DN 12 do DN 50 (DVGW G 5616, 2012).

Zgodnie z tymi przepisami wszystkie elementy systemów falistych powinny spełniać wymagania normy DIN EN 15266 oraz dodatkowe wymagania zawarte w tych wytycznych.

Dodatkowymi wymaganiami, poza opisanymi w EN 15266, są (DVGW G 5616, 2012):

- dla uszczelnień: wymagania DVGW VP 406,

- p. 5.3. Relaksacja naprężén pod naciskiem,

- p. 6.1. Odporność na odkształcenia pod naciskiem,

- p. 7. Materiat - dopuszczone zostały do stosowania materiały uszczelniające na bazie włókien syntetycznych, grafitu lub politetrafluoroetylenu (PTFE) zgodnie z DIN 3535-6;

- dla złączy dopuszcza się stosowanie gwintów zgodnych z EN ISO 228-1 w klasie tolerancji B z płaską uszczelką; - dla połączeń i ich „odporności w przypadku ognia” standard wymaga przeprowadzenia badania ,szczelność w przypadku ognia" nie przy ciśnieniu według deklaracji producenta, jak to opisano w normie DIN EN 15266, ale obligatoryjnie przy ciśnieniu 100 mbar.

W Austrii również można stosować te systemy, natomiast obowiązują wytyczne techniczne OVGW (OVGW G K21, 2018). Opisują one wymagania dla instalacji gazowych dotyczące projektowania, wykonania, konstrukcji i eksploatacji. W odniesieniu do systemów faliście giętkich rur ze stali nierdzewnej wytyczne wskazują w p. 4.2.7, aby systemy te spełniały wymagania określone w wytycznych do badań PG 315 OVGW do ciśnienia roboczego 500 mbar. Wytyczne te określają wymagania i badania niezbędne do przyznania znaku jakości ÖVGW. Oprócz tych wytycznych technicznych elementy systemu muszą spełnić wymagania normy ONORM EN 15266:2007.

Podsumowując, na podstawie analizowanych norm i przepisów widać, że pomimo iż Polska Norma PN-EN 1775:2009 dopuszcza faliście giętkie przewody ze stali nierdzewnej do budowy instalacji gazowych, to przepisy prawne obowiązujące w tym zakresie w Polsce, czyli rozporządzenie Ministra Infrastruktury w sprawie warunków technicznych, jakim powinny odpowiadać budynki i ich usytuowanie, w swych zapisach nie zezwalają na wykonanie instalacji gazowych z tych systemów. Również w innych krajach stosowanie systemów faliście giętkich przewodów ze stali nierdzewnej służących do budowy instalacji gazowych w budynkach zostało dopuszczone, jednak prawie każdy opisany w artykule kraj określił dodatkowe wymagania w stosunku do tych systemów, zwiększając bezpieczeństwo ich stosowania.

\section{Program badań}

W celu wstępnego sprawdzenia przydatności systemów faliście giętkich rur ze stali nierdzewnej do instalacji gazowych w budynkach wytypowano kilka badań z normy PN-EN 15266:2009, które były najbardziej istotne ze względu na wytrzymałość systemu i bezpieczeństwo w razie pożaru.

W tabeli 3 przedstawiono wykaz wytypowanych właściwości i metod badawczych według normy PN-EN 15266:2009.

Do badań wytypowano po dwie średnice nominalne przewodów o wymiarach około DN 25-28 oraz DN 50. Próbki o średnicy DN 50 zostały poddane tylko badaniom odporności w przypadku ognia. 
Tabela 3. Wytypowane właściwości do badań

Table 3. Properties selected for testing

\begin{tabular}{|l|c|}
\hline \multicolumn{1}{|c|}{ Rodzaj badania } & $\begin{array}{c}\text { Wymagania i badania } \\
\text { według PN-EN 15266:2009 }\end{array}$ \\
\hline \hline Szczelność & 5.2 \\
\hline Zdolność zginania & 5.4 \\
\hline Wytrzymałość na ciśnienie & 5.8 \\
\hline Odporność na uderzenie & 5.9 \\
\hline Wytrzymałość na wgniecenie & 5.10 \\
\hline Wytrzymałość na rozciąganie & 5.11 \\
\hline Szczelność w przypadku ognia & 5.15 \\
\hline
\end{tabular}

\section{Badania}

Badania zostały przeprowadzone w Instytucie Nafty i Gazu - Państwowym Instytucie Badawczym, w Zakładzie Przesyłania i Dystrybucji Gazu oraz w Zakładzie Metrologii Przepływów.

Badaniami objęto następujące właściwości:

- Próba szczelności - badaną próbkę poddano próbie ciśnieniowej ciśnieniem 2 bar. Próbkę utrzymuje się pod wodą, szybkość wycieku nie powinna przekraczać $10 \mathrm{~cm}^{3} / \mathrm{h}$. Ze względu na możliwości badawcze kryterium akceptacji: $100 \%$ szczelności.

- Zdolność zginania - badanie odporności na zginanie polegało na wykonaniu 12 cykli zginania o $180^{\circ}$ przewodu rurowego po kolistym łuku o określonym promieniu gięcia. Kryterium akceptacji: szczelny, brak pęknięć.

- Próba wytrzymałości na ciśnienie - badaną próbkę poddano ciśnieniu wewnętrznemu 15 bar na okres $(300+10 /-0)$ s. Kryterium akceptacji: zachowanie szczelności.

- Odporność na uderzenie - próbkę poddano uderzeniu energią $30 \mathrm{~J} \mathrm{w}$ miejscu łącznika PLT. Kryterium akceptacji: zachować szczelność podczas badania.

- Wytrzymałość na wgniecenie - badanie wytrzymałości na wgniecenie polega na zrzuceniu z wysokości $300 \mathrm{~mm}$ ciężarka o masie $5 \mathrm{~kg}$ w pobliżu złącza PLT. Szew giętkiego przewodu podczas badania powinien znajdować się pod kątem prostym do kierunku działania siły. Kryterium akceptacji: zachowanie szczelności.

- Wytrzymałość na rozciąganie - do próbki przyłożono osiowe obciążenie 100 razy DN w niutonach. Należy stopniowo przykładać siłę do próbki od $50 \mathrm{~N} / \mathrm{s}$ i pełne obciążenie powinno być utrzymywane przez $10 \mathrm{~min}$. Kryterium akceptacji: zachowanie szczelności.

- Szczelność w przypadku ognia - próbkę poddano działaniu wysokiej temperatury: $650^{\circ} \mathrm{C}$, podczas badania w próbce należy utrzymywać ciśnienie 50 mbar. Kryterium akceptacji: wynik badania uznaje się za pozytywny, jeżeli podczas trwania 30-minutowej próby dopuszczalny wyciek nie przekracza $150 \mathrm{dm}^{3} / \mathrm{h}$.

$\mathrm{Z}$ uwagi na to, że systemy faliście giętkich przewodów ze stali nierdzewnej do budowy instalacji gazowych nie były jeszcze przedmiotem badań w Polsce, a na rynku krajowym wyrób ten nie jest wprowadzany do obrotu, zdecydowano o wytypowaniu do badań wyrobów co najmniej trzech producentów, zwracając uwagę na to, aby systemy te różniły się konstrukcyjnie i pod względem zastosowanego systemu uszczelnień. Produkty do badań pochodziły z rynku w Wielkiej Brytanii i Austrii.

Ostatecznie do badań wytypowano systemy:

- z uszczelnieniem elastycznym;

- bez dodatkowego uszczelnienia;

- $\quad \mathrm{z}$ dodatkowym pierścieniem ze stopu miedzi.

\section{System z uszczelnieniem elastycznym firmy BOAGAZ}

W tym systemie szczelność połączenia uzyskana jest za pomocą uszczelnienia miękkiego.

System obejmuje redukcje, złączki proste do łączenia dwóch odcinków rur falistych, trójniki oraz złączki końcowe itp. Zakres średnic: DN 15 do DN 50, ciśnienie robocze: do 500 mbar.

Na rysunku 1 można zobaczyć poszczególne elementy złączki.

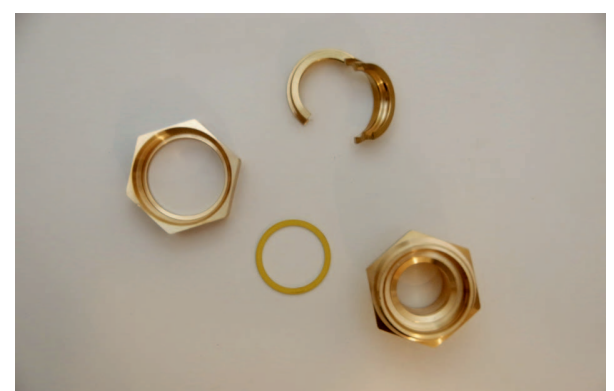

Rys. 1. Elementy złączki z uszczelnieniem miękkim (fot. T. Minor) Fig. 1. Couplings with soft sealing (photo by T. Minor)

\section{System bez dodatkowych uszczelnień firmy TracPipe}

W tym systemie szczelność połączenia uzyskana jest bez dodatkowego uszczelnienia. System obejmuje redukcje, złączki proste do łączenia dwóch odcinków rur falistych, trójniki, złączki końcowe, przejścia z rury falistej na systemy z rur miedzianych wykonane poprzez połączenia zaciskane itp. Zakres

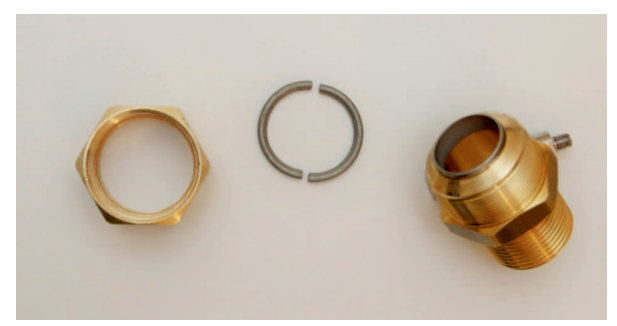

Rys. 2. Elementy złączki bez uszczelnień (fot. T. Minor)

Fig. 2. Coupling elements without seals (photo by T. Minor) 
średnic: DN 12 do DN 50, ciśnienie robocze: do 500 mbar. Rysunek 2 przedstawia elementy tego systemu.

\section{System z uszczelnieniem z podktadka ze stopu miedzi firmy Flexigas}

W tym systemie szczelność połączenia uzyskana jest za pomocą dodatkowego uszczelnienia wykonanego z podkładki ze stopów miedzi.

System obejmuje redukcje, złączki proste do łączenia dwóch odcinków rur falistych, trójniki oraz złączki końcowe itp. Zakres średnic: DN 15 do DN 32, ciśnienie robocze do 500 mbar.

$\mathrm{Na}$ rysunku 3 zaprezentowano system z uszczelnieniem z podkładką ze stopu miedzi.

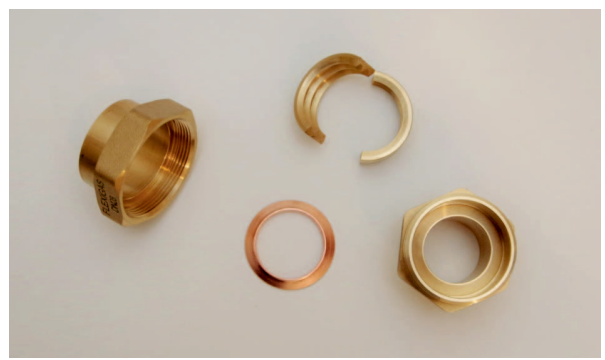

Rys. 3. Łącznik prosty systemu z uszczelnieniem ze stopu miedzi (fot. T. Minor)

Fig. 3. System straight connector with copper alloy seal (photo by T. Minor)

\section{Analiza wyników}

W trakcie prowadzenia wytypowanych badań nie zaobserwowano negatywnych wyników. W procesie przygotowywania próbek do badań bardzo istotne jest staranne przygotowanie końców rury przed przystąpieniem do montażu systemu. Podczas próby szczelności, zginania, odporności na uderzenie oraz odporności na wgniecenie wszystkie próbki spełniły wymagania normy (PN-EN 15266:2009). Rysunki 4 i 5 przedstawiają próbki po badaniach odporności na wgniecenie i uderzenie.

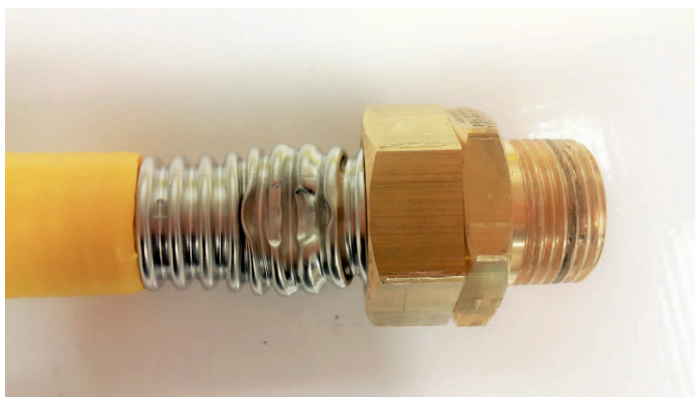

Rys. 4. Próbka bez dodatkowego uszczelnienia po badaniu odporności na wgniecenie (fot. T. Minor)

Fig. 4. Sample without additional sealing after dent resistance test (photo by T. Minor)

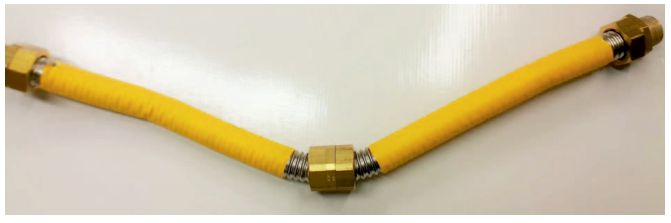

Rys. 5. Próbka z uszczelnieniem miękkim po badaniu odporności na uderzenie (fot. T. Minor)

Fig. 5. Soft-seal sample after impact resistance test (photo by T Minor)

Podczas badań szczelności w przypadku ognia zaobserwowano wycieki w próbkach z uszczelnieniem miękkim, jednakże wycieki te nie przekraczały dopuszczalnych ilości określonych w normie (PN-EN 15266:2009, PN-EN 1775:2009). Rysunki 6 i 7 przedstawiają widok próbek po badaniu odporności w przypadku ognia.

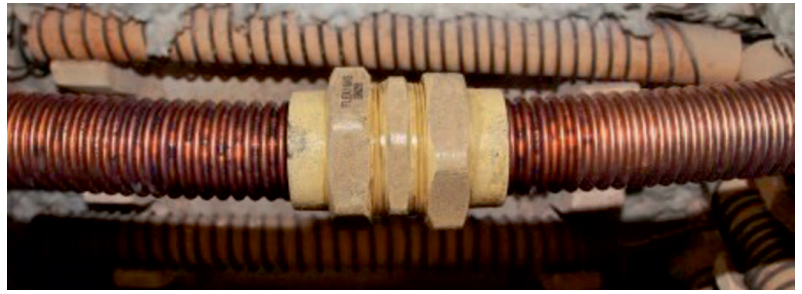

Rys. 6. Próbka DN 28 po badaniu szczelności w przypadku ognia Fig. 6. DN 28 sample after leakage in case of fire test

Podczas tego badania najlepsze wyniki uzyskały systemy bez dodatkowych uszczelnień lub z uszczelnieniem w postaci podkładki ze stopów miedzi (twarde).

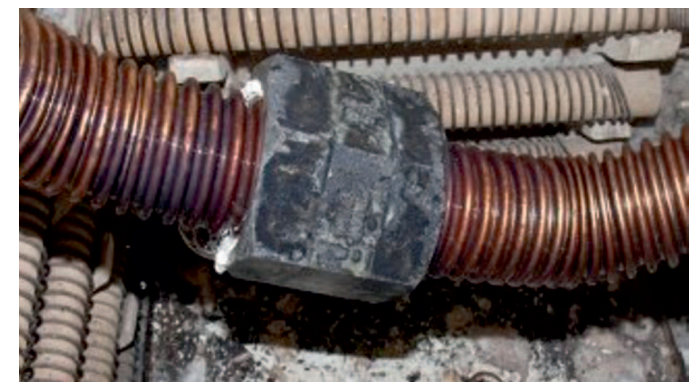

Rys. 7. Próbka DN 50 po badaniu szczelności w przypadku ognia Fig. 7. DN 50 sample after leakage in case of fire test

\section{Ocena możliwości stosowania systemów faliście giętkich ze stali nierdzewnej do budowy instalacji gazowych w budynkach w Polsce}

Na podstawie wyników badań i przeprowadzonego studium literaturowego można stwierdzić, że systemy elastycznych przewodów metalowych faliście giętkich nadają się do stosowania do budowy instalacji gazowych budynków. Wymaga to jednak zmian w obecnych przepisach krajowych oraz być może stworzenia dodatkowych krajowych wytycznych. Wytyczne 
takie, wzorem innych krajów, powinny zawierać m.in. wymagania co do projektowania, wykonywania i eksploatacji instalacji zbudowanych z systemów elastycznych przewodów metalowych faliście giętkich.

Mając na uwadze względy bezpieczeństwa związane z eksploatacją instalacji gazowych, należy wziąć pod uwagę wprowadzenie dodatkowych wymagań rozszerzających zapisy dotyczące wymagań i badań w normie PN-EN 15266:2009.

Dodatkowymi wymaganiami powinny być np.:

- badanie połączeń spawanych rury;

- odporność układu łącznik-rura-lącznik na skręcanie;

- sprawdzenie momentu montażowego;

- badanie skręcania i zginania łączników;

- trwałość uszczelnień.

Poza tym należy wprowadzić wymóg:

- dostarczenia instrukcji instalowania systemu w języku polskim

oraz zmienić parametry wybranych badań na wyższe, np.:

- wyższe ciśnienie podczas przeprowadzania próby szczelności w przypadku ognia.

Zgodnie z obecną praktyką w Polsce - podczas badań innych elementów instalacji gazowych ciśnienie próby szczelności w przypadku ognia dla np.:

- złączek zaprasowywanych z miedzi i stopów miedzi jest równe maksymalnemu ciśnieniu roboczemu o wartości co najmniej 100 mbar, a w praktyce z reguły wynosi 1 bar lub więcej;

a w przypadku badań według normy PN-EN 14800:2010:

- bezpiecznych elastycznych metalowych przewodów z rur falistych do przyłączania domowych urządzeń zasilanych paliwami gazowymi wynosi 100 mbar.

Dodatkowe wymagania powinny być określone przez grono specjalistów.

\section{Podsumowanie}

Podsumowując, systemy faliście giętkich przewodów ze stali nierdzewnej mają swoich zwolenników i przeciwników. Niewątpliwie zaletą tych systemów jest możliwość prowadzenia instalacji bez stosowania dodatkowych łączników, kolan lub zmniejszenia ich liczby do minimum. W przypadku niewłaściwego wykonania instalacji odgromowej, uziemiającej oraz nieodpowiedniego uziemienia przewodów falistych może w momencie wyładowań atmosferycznych dojść do uszkodzenia ścianek rur. Budowa instalacji jest szybka i nie wymaga specjalistycznych narzędzi.

Uzyskanie pozytywnych wyników wybranych badań wykonanych zgodnie z normą PN-EN 15266:2009 może nie być wystarczające do zapewnienia bezpiecznego stosowania systemów faliście giętkich przewodów ze stali nierdzewnej do budowy instalacji gazowych w Polsce z uwagi na inne, bardzo ważne aspekty wynikające z przeprowadzonej analizy przepisów obowiązujących w wybranych krajach Unii Europejskiej. Konieczne jest zatem określenie dodatkowych wytycznych do:

- projektowania;

- wykonywania (kultura pracy);

- eksploatacji instalacji gazowych zbudowanych z systemów faliście giętkich przewodów ze stali nierdzewnej.

Ponadto, po przeprowadzonej analizie przepisów stosowanych w innych krajach, wydaje się zasadne wprowadzenie dodatkowych wymagań dla wyrobu, wykraczających poza obszar normy PN-EN 15266:2009, co będzie skutkować koniecznością uzyskania krajowej oceny technicznej, umożliwiającej przeprowadzenie oceny i weryfikacji stałości właściwości użytkowych wyrobu oraz deklarowanie tych właściwości przed wprowadzeniem wyrobu do obrotu na polski rynek.

Wprowadzenie w przepisach krajowych zmian umożliwiających stosowanie systemów faliście giętkich przewodów ze stali nierdzewnej do budowy instalacji gazowych w budynkach powinno być poprzedzone konsultacjami w szerokim gronie specjalistów i ekspertów oraz ze służbami odpowiedzialnymi za eksploatowanie instalacji gazowych.

Artykuł powstał na podstawie pracy statutowej pt.: Analiza możliwości stosowania systemów faliście giętkich przewodów ze stali nierdzewnej w instalacjach gazowych budynków w Polsce - praca INiG - PIB na zlecenie MNiSW; nr zlecenia: 0093/GP/2018, nr archiwalny: DK-4100-0085/2018.

\section{Literatura}

Brady M., 2015. Flexible Gas Lines a Possible Fire Hazard. <https:// www.angieslist.com/articles/flexible-gas-lines-possible-firehazard.htm> (dostęp: 21.07.2019).

Friedman S., 2015. Experts Say Flexible Gas Line Lightning-Related Fires Continue in Spite of New Safety Measures. <https://www. nbcdfw.com/investigations/Experts-Say-Flexible-Gas-LineLightning-Related-Fires-Continue-in-Spite-of-New-SafetyMeasures-246966451.html> (dostęp: 21.07.2019).

Minor T., 2017a. Analiza możliwości poprawy bezpieczeństwa eksploatacji instalacji gazowych - przyczyny wypadków oraz rozwiązania pozwalające na minimalizację ich liczby. Nafta-Gaz, 6: 411-421. DOI: 10.18668/NG.2017.06.06.

Minor T., 2017b. Analiza stanu techniczno-prawnego instalacji gazowych w Polsce pod względem bezpieczeństwa ich eksploatacji - propozycje zmian. Nafta-Gaz, 11: 887-893. DOI: 10.18668/ NG.2017.11.09.

Wróblewska A., 2010. Ocena możliwości stosowania w instalacjach gazowych systemów rur wielowarstwowych z tworzyw sztucznych. Nafta-Gaz, 7: 597-601.

\section{Akty prawne i normatywne}

BS 6891:2015 Specification for the installation and maintenance of low pressure gas installation pipework of up to $35 \mathrm{~mm}$ (R11/4) on premises. 
BS 7838:1996 Corrugated stainless steel semi-rigid pipe and associated fittings for low-pressure gas pipework of up to DN 50.

BS EN 15266:2007 Stainless steel pliable corrugated tubing kits in buildings for gas with an operating pressure up to 0.5 bar.

CCH 2007-01 Juin 2014. Kits de tuyaux onduleux pliables en acier inoxydable pour le gaz dans les batiments avec une pression de service inferieure ou egale a 0,5 bar (Kits «PLT»).

DIN EN 15266 Nichtrostende biegbare Wellrohrsysteme in Gebäuden mit einem Arbeitsdruck bis 0,5 bar; Deutsche Fassung prEN 15266:2005.

DVGW G 5616 (P) April 2012. Biegbare Wellrohrbausätze aus nichtrostendem Stahl mit einem Betriebsdruck bis 500 mbar nach DIN EN 15266 - Maße, Übergangsverbinder, ergänzende betriebliche Anforderungen.

DVGW G 600 (A) Mai 2017. Technische Regel für Gasinstallationen (DVGW-TRGI).

NF DTU 61.1 P1 Compil Août 2006 Installations de gaz dans les locaux d'habitation Partie 1: terminologie.

NF DTU 61.1 P2 Compil Août 2006 Travaux de bâtiment Installations de gaz dans les locaux d'habitationPartie 2: Cahier des clauses techniques - Dispositions générales.

NF EN 15266 Août 2007. Kits de tuyaux onduleux pliables en acier inoxydable pour le gaz dans les bâtiments avec une pression de service inférieure ou égale à 0,5 bar.

ONORM EN 15266:2007 Stainless steel pliable corrugated tubing kits in buildings for gas with an operating pressure up to $0.5 \mathrm{Bar}$ (Austrian Standard).

OVGW G K21 2018-12 Errichtung, Änderung und Fertigstellungsprüfung on Leitungen.

PN-EN 14800:2010 Bezpieczne metalowe przewody przyłączeniowe faliście giętkie do przyłączania urządzeń domowych zasilanych paliwami gazowymi.

PN-EN 15266:2009 Systemy faliście giętkich przewodów rurowych ze stali odpornej na korozję do zastosowań w instalacjach gazowych w budynkach, o ciśnieniu roboczym nie przekraczającym 0,5 bar.
PN-EN 1775:2009 Dostawa gazu - Przewody gazowe dla budynków - Maksymalne ciśnienie robocze równe 5 bar lub mniejsze - Zalecenia funkcjonalne.

Rozporządzenia Ministra Infrastruktury z dnia 12 kwietnia 2002 r. w sprawie warunków technicznych, jakim powinny odpowiadać budynki i ich usytuowanie (Dz.U. z 2015 r. poz. 1422 z późn. zm.).

Rozporządzeniem Ministra Infrastruktury i Budownictwa $z$ dnia 17 listopada 2016 r. w sprawie sposobu deklarowania właściwości użytkowych wyrobów budowlanych oraz sposobu znakowania ich znakiem budowlanym (Dz.U. z 2016 r. poz. 1966).

STN EN 15266 Zostavy ohybných vlnovcových potrubí z nehrdzavejúcej ocele na rozvod plynu v budovách s prevádzkovým tlakom do 0,5 bar.

TPP 70401 Jul 2009. Odberné plynové zariadenia na zemný plyn $\mathrm{v}$ budovách.

TPP 70404 August 2016. Použitie vlnovcových ohybných potrubí z nehrdzavejúcej ocele na rozvody plynu v budovách s prevádzkovým tlakom do $50 \mathrm{kPa}$ vrátane.

Ustawa z dnia 16 kwietnia 2004 r. o wyrobach budowlanych (t.j. Dz.U. z 2016 r. poz. 1570 z późn. zm.).

XP E29-826 Novembre 2017. Kits de tuyaux onduleux pliables en acier inoxydable pour le gaz avec une pression de service jusqu'à 2 bar.

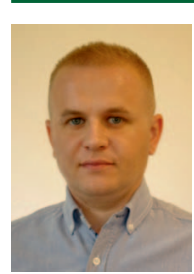

Mgr inż. Tomasz MINOR

Główny specjalista inżynieryjno-techniczny w Zakładzie Przesyłania i Dystrybucji Gazu; Kierownik Laboratorium Badań Armatury i Technik Eksploatacji Gazociągów Instytut Nafty i Gazu - Państwowy Instytut Badawczy ul. Lubicz 25 A, 31-503 Kraków E-mail: tomasz.minor@inig.pl

\section{OFERTA BADAWCZA ZAKKADU PRZESYŁANIA I DYSTRYBUCJI GAZU}

badania rur, ksztattek i armatury z tworzyw sztucznych stosowanych do budowy sieci gazowych, wodociagowych oraz do ciśnieniowej kanalizacji deszczowej i sanitarnej;

badania systemów przewodów rurowych do instalacii wody cieptej i zimnej wewnątrz budynków np. PE-X/AL/PE-X, PP, PB, PE-X badania armatury metalowei do sieci i instalacii gazowych oraz wodociagowych;

badania armatury do instalacji centralnego ogrzewania i solarnych;

badania armatury sanitarnej, np. baterii mechanicznych, termostatycznych; mieszających, zaworów wyptywowych, natrysków i przewodów natryskowych;

badania reduktorów średniego ciśnienia;

badania powtok ochronnych z tworzyw sztucznych na rurach i armaturze stalowej;

ocena stopnia zagrożenia korozyjnego gazociagów stalowych oraz ocena stanu technicznego izolacji gazociagów stalowych metodami bezwykopowymi;

analiza zagrożeń korozyjnych na tłoczniach i magazynach gazu oraz instalacji związanych z ropociągami, wodociągami i podziemnymi zbiornikami;

ocena efektywności metod rekonstrukcii sieci dystrybucyinych gazu;

badania z zakresu wspótpracy ośrodka gruntowego z siecią gazową na terenach górniczych;

opiniowanie projektów przepisów oraz norm związanych z budową i użytkowaniem sieci gazowych;

prowadzenie specjalistycznych szkoleń z zakresu budowy sieci gazowych z polietylenu z zastosowaniem technologii zgrzewania doczotowego i elektrooporowego:

szkolenie i kwalifikacja personelu zgrzewającego rury i ksztattki z PE wg PN-EN 13067 w INiG-PIB jako Ośrodku Szkoleniowym i Egzaminacyjnym uznanym przez UDT-CERT;

ocena jakości połaczeń zgrzewanych rur i kształtek z PE na potrzeby kwalifikacii personelu zgrzewającego wg normy PN-EN 13067 w Laboratorium Tworzyw Sztucznych uznanym przez UDT;

wspomaganie przemystu we wdrażaniu nowych rozwiązań technicznych oraz opracowywanie ekspertyz i analiz.

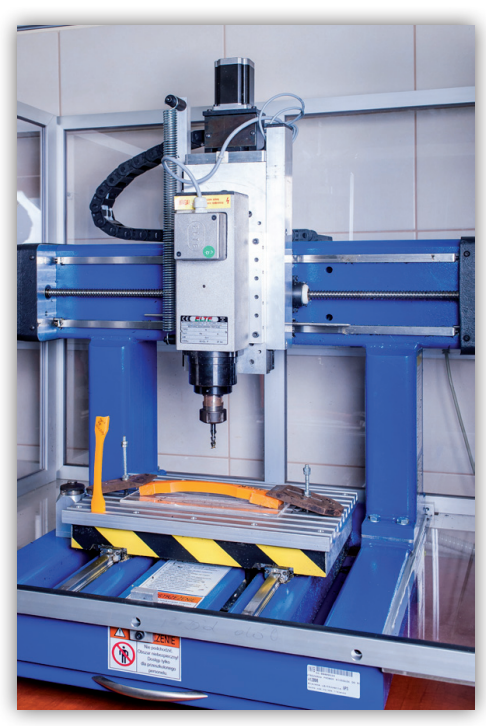

INSTYTUT NAFTY I GAZU

- Państwowy Instytut Badawczy 